\title{
The potential of periphyton-based cage culture of Nile tilapia in a Brazilian reservoir
}

\author{
F. Garcia ${ }^{\text {a,* }}$, D.M. Romera ${ }^{\text {b }}$, N.S. Sousa ${ }^{\text {a }}$, I. Paiva-Ramos ${ }^{\text {c }}$, E.M. Onaka ${ }^{\text {a }}$ \\ a Instituto de Pesca, APTA/SAA, Rodovia Washington Luiz (SP 310) km 445, 15025-970, São José do Rio Preto, SP, Brazil, Postal Box 61, 15500-970 Votuporanga, SP, Brazil \\ ${ }^{\mathrm{b}}$ Instituto Agronômico de Campinas, APTA/SAA, Postal Box 61, 15500-970 Votuporanga, SP, Brazil \\ " FEIS - Universidade Estadual Paulista "Julio de Mesquisata Filho" - UNESP, Avenida Brasil, 56 - Centro, - 15385-000 - Ilha Solteira, SP, Brazil
}

\section{A R T I C L E I N F O}

\section{Article history:}

Received 15 December 2015

Received in revised form 21 June 2016

Accepted 22 June 2016

Available online 23 June 2016

\section{Keywords:}

Bamboo substrate

Stocking density

Feed restriction

Monogenean

Trichodina

Growth performance

\begin{abstract}
A B S T R A C T
In land-based pond cultures, periphyton is considered to be a complementary food source for cultured fish. In cage aquaculture, studies on the use of periphyton are scarce and do not support the viability of periphytonbased cage culture. The aim of this study was to evaluate the potential of periphyton-based cage culture of Nile tilapia in a hydroelectric reservoir in Brazil at three stocking densities and two feeding regimes. Sex-reversed male Nile tilapia Oreochromis niloticus $(46.56 \pm 2.53 \mathrm{~g})$ were placed in 21 cages $\left(6 \mathrm{~m}^{3}-2 \times 2 \times 1.5 \mathrm{~m}\right.$ each) with or without bamboo substrates for periphyton growth. A completely randomized design with three replicates per treatment was used to test the effect of substrate inclusion in the three stocking densities $(80,60$, $40 \mathrm{~kg}$ of fish $/ \mathrm{m}^{3}$ ) associated with two feeding regimes ( $100 \%$ and $50 \%$ of daily ration). Three cages without bamboo substrates were included in the experimental design as control group (CTRL) $\left(80 \mathrm{~kg} / \mathrm{m}^{3}\right.$ and $100 \%$ of daily ration). The study demonstrates the efficiency of using substrates for Nile tilapia in cages in the reservoir. The presence of bamboo substrates improved the weight gain of fish but reduced the carrying capacity of the cage at the highest density. The concentration of dissolved oxygen in the cages was improved by the presence of substrate between 50 and 140 days of the trial and reduced after 155 days of culture. The inclusion of bamboo substrates inside the cages allows producing up to $52 \mathrm{~kg} / \mathrm{m} 3$ of Nile tilapia using 32\% less diet in a period almost 20\% shorter than in the CTRL group. If farmers prefer to produce $80 \mathrm{~kg} / \mathrm{m} 3$, they can use $30 \%$ less diet but the production period would be $20 \%$ longer.

Statement of relevance: This study has high relevance to the general field of commercial aquaculture because the experiment was carried out at a commercial fish farm, under real environmental conditions and management. Presented results are promising because show that bamboo substrates in cages improve the efficiency of the system up to $52 \mathrm{~kg} / \mathrm{m} 3$. This production model may be an efficient alternative for family farmers.
\end{abstract}

(c) 2016 Elsevier B.V. All rights reserved.

\section{Introduction}

In 2011 the global tilapia production totalled 3,957,843 T. Brazil is one of the top 10 tilapia producers and supplied $88 \%$ of that amount (GLOBEFISH Highlights, 2013). Because of their 6.5 million ha of water reservoirs, lakes and dams, Brazil has conditions to improve its cage farming (Rojas and Wadsworth, 2007). The Brazilian tilapia production grew by $63 \%$ over a period of one year since 2010 (GLOBEFISH Highlights, 2013).

Tilapias are omnivorous and feed at a low trophic level. Within intensive systems, these species can be fed formulated diets containing a high percentage of plant proteins and oils (Watanabe et al., 1992). Most tilapias are able to use phytoplankton and periphyton as an energy

\footnotetext{
* Corresponding author.

E-mail address: fgarcia@apta.sp.gov.br (F. Garcia).
}

source. However, studies by Dempster et al. (1993) have demonstrated that ingestion rates of tilapias are up to 25 times higher when algae are provided as periphyton than when they are provided as phytoplankton.

Periphyton is the community of microorganisms that colonizes on submerged plants, stones and other substrates. In land-based pond cultures, periphyton production is considered to be a complementary food source for cultured fish (Azim et al., 2005). In cage aquaculture and in intensive aquaculture systems, studies on the use of periphyton are scarce and do not support the viability of periphyton-based cage culture. Norberg (1999) investigated the potential production of periphyton in cages with a mixed tilapia culture of Oreochromis mortimeri, Tilapia rendalli and Oreochromis niloticus (Linnaeus) in Lake Kariba, Zimbabwe. The authors calculated that the primary production of periphyton in the cage was $1 \%$ relative to the energy demands of the fish. Huchette and Beveridge (2003) evaluated the potential for periphyton-based cages of Nile tilapia (GIFT) in the Meghna-Gumti River (Bangladesh). Their 
results showed that periphyton-based aquaculture was not economically viable and that the primary economic constraints were the costs of the cage material (net and bamboo poles) and fry.

Conversely, a new study showed that decreasing the dietary protein levels in the presence of periphyton substrates can improve the performance of Nile tilapia juveniles reared in floating cages in an earthen pond. Indeed, this approach is more cost-effective than the group that received higher protein levels and no periphyton (Sakr et al., 2015). In Brazil, Garcia et al. (2013) showed that reducing the stocking density of Nile tilapia juveniles in cages in hydroelectric reservoirs from $80 \mathrm{~kg} / \mathrm{m} 3$ to $30 \mathrm{~kg} / \mathrm{m} 3$ significantly decreases their feed conversion ratio from 1.36 to 0.95 . These authors proposed that natural food such as phytoplankton and periphyton should be making part of the diet of fish and that the cage nets can act as a substrate for periphyton growth. Thus, the aim of this study was to evaluate the potential of periphyton-based cage culture of Nile tilapia in a hydroelectric reservoir in Brazil at three stocking densities and two feeding regimes.

\section{Material and methods}

The experiment was conducted in a cage-fish farm located in São Jerônimo Stream, Nova Avanhandava reservoir, Tietê River, São Paulo, Brazil ( $21^{\circ} 11^{\prime} 27.41^{\prime \prime}$ S, 50 $03^{\prime} 00.79^{\prime \prime}$ W). A total of 1812 sex-reversed male Nile tilapia Oreochromis niloticus $(46.56 \pm 2.53 \mathrm{~g})$ were placed in 21 cages $\left(6 \mathrm{~m}^{3}-2 \times 2 \times 1.5 \mathrm{~m}\right)$ of which 18 with bamboo substrates for periphyton growth. Inside each cage, five modules of bamboo substrate (area of each module: $2.21 \pm 0.12 \mathrm{~m}^{2}$; total area: $11.05 \mathrm{~m}^{2}$ ) were installed. Modules were made using bamboo rods cut lengthwise into halves. Each module was composed of seven vertical bamboos $(1 \mathrm{~m})$ attached at their borders to two horizontal bamboos $(2 \mathrm{~m})$ and fixed by one diagonal bamboo. Galvanized wire was used to bind the bamboo rods (Fig. 1).

Positioning of cages in the reservoir was made in lines leaving $5 \mathrm{~m}$ between each line. 21 cages were fixed in each line with a distance of $1.5 \mathrm{~m}$ between them. Lines were positioned against the water current and perpendicular to the reservoir border, allowing water movement for the removal of wastes. The regular routine labor-adopted by farmers was used and there was no management to clean cage-netting.

A preliminary experiment conducted in the same water body showed that on the day 21st, periphyton growth was stable $\left(0.95 \mathrm{mg} / \mathrm{cm}^{2}\right.$ of dry matter) and could be offered to fish as a complementary food. Thus, in this trial fish were introduced into cages on the day 21st after the bamboo substrates were installed.

A completely randomized design was used to test the inclusion of substrates in three stocking densities (80,60,40 kg of fish $/ \mathrm{m}^{3}$ ) associated with two types of feeding regimes ( $100 \%$ and $50 \%$ of daily ration) with three replicates. Three cages without bamboo substrates were included in the experimental design as control group (CTRL). In the control group, fish were stocked at the highest stocking density $\left(80 \mathrm{~kg} / \mathrm{m}^{3}\right)$ and fed two meals a day (100\% of daily ration), according to the usual regimen used by Brazilian fish farmers. We included this treatment in order to compare all treatments with substrate to the production system usually adopted by Brazilian farmers, and propose a more efficient production model of Nile tilapia in cages. The three stocking densities were calculated considering the expected final weight of $800 \mathrm{~g}$ for fish.

In the morning, dead and moribund fish were removed. The group of fish that received $100 \%$ of daily ration was fed twice a day (8:00 h and 16:00 h), and the group that received one meal daily (half amount of daily ration) was fed only in the afternoon (16:00 h). The goal of this approach was to stimulate fish to eat periphyton during day time.

The amount of each diet portion (according the recommendation of the industry of feed - Table 1) was offered slowly by hand until visual apparent satiety. Fish weighing 40 to $250 \mathrm{~g}$ were fed 3 to 4 -mm pelleted commercial feed (dry matter: $88 \%$, crude protein: $36 \%$, ether extract $8 \%$ ).
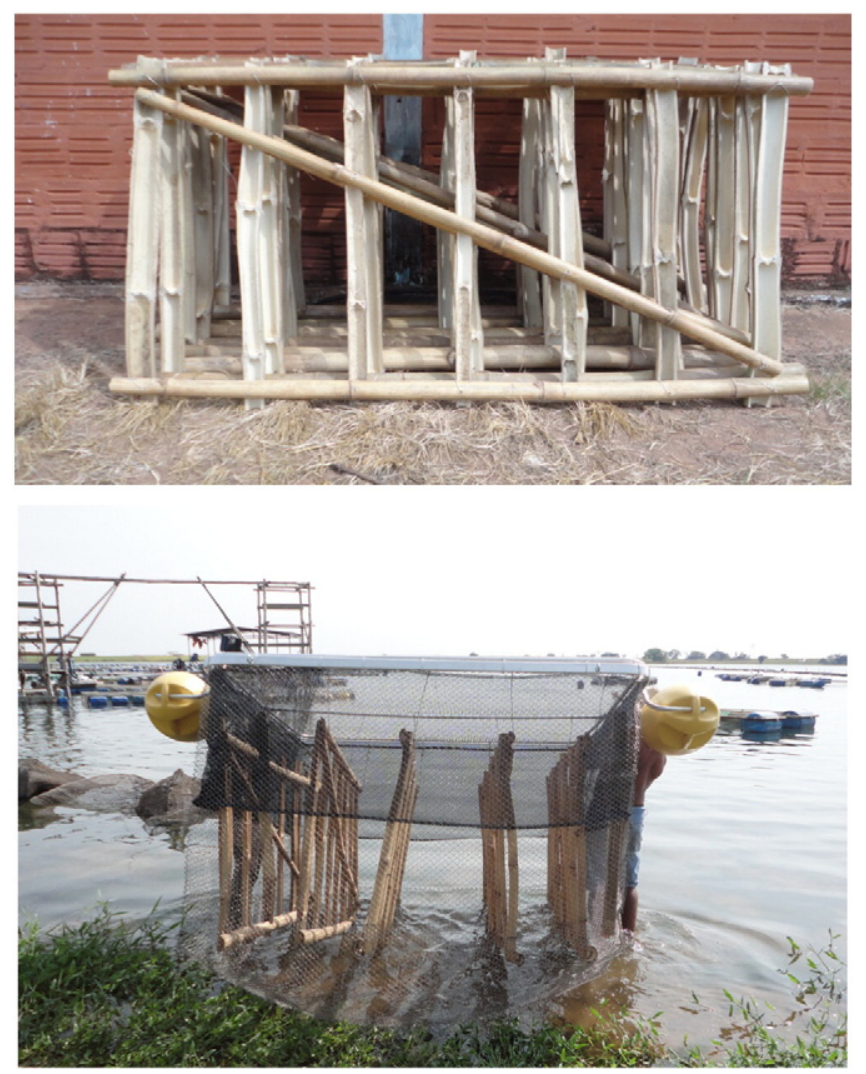

Fig. 1. Modules of bamboo rods cut into halves lengthwise as substrate to periphyton growth installed within cages $\left(6 \mathrm{~m}^{3}-2 \times 2 \times 1.5 \mathrm{~m}\right)$. Each module was composed of seven vertical bamboos $(1 \mathrm{~m})$ attached at their borders on two horizontal bamboos $(2 \mathrm{~m})$ and fixed by one diagonal bamboo rod.

For bigger fish weighing $250 \mathrm{~g}$ to $800 \mathrm{~g}$, the producers use 6 to $8-\mathrm{mm}$ feed pellets of lower protein (32\%) and lipid (6\%) contents.

\subsection{Growth performance}

Individual fish weighing was performed on $5 \%$ of the fish per cage at the beginning and at the end of the trial to evaluate growth performance and size uniformity of the lot (coefficient of variation).

Feed consumed was recorded daily and fish were fed 6 days a week. During the experiment, biometry was performed on five samples (approximately 10 fish each) in each cage every two weeks to calculate the amount of diet to offer to fish and to ascertain whether the target average weight of the fish had reached $800 \mathrm{~g}$.

The parameters evaluated were the following: weight gain (WG) = final weight - initial weight; feed conversion ratio (FCR) $=$ WG / feed consumed; specific growth rate $($ SGR $)=100 \times($ Ln final weight - Ln initial weight) / number of days; coefficient of variation $(\mathrm{CV})=$ standard deviation of fish weight (FW) / average weight (AW).

To study the ability of tilapia to consume periphyton at each growth phase, growth performance parameters were evaluated when the fish were 300, 500 and $800 \mathrm{~g}$.

Table 1

Diet portions offered to Nile tilapia in each growth phase, according the recommendation of the industry of feed.

\begin{tabular}{lc}
\hline Average fish weight $(\mathrm{g} / \mathrm{fish})$ & Daily feed rate $(\%$ of fish weight $)$ \\
\hline $45-150$ & 5.5 \\
$151-315$ & 4.0 \\
$316-500$ & 2.8 \\
$501-650$ & 2.0 \\
$651-800$ & 1.6 \\
\hline
\end{tabular}




\subsection{Water quality}

Temperature and dissolved oxygen were measured daily in the morning inside each cage (50 cm deep) using an YSI 700 oximeter. Environmental water samples around the cages were collected at the beginning and the end of the experiment to characterize the reservoir site where the experiment was carried out. Concentrations of total phosphorus and total nitrogen were determined according to Valderrama (1981) by a colorimetric method. The photosynthetic pigment chlorophyll $a$ was determined by spectrophotometry according to Marker et al. (1980). An YSI EcoSense pH100A meter was used to determine the $\mathrm{pH}$ and transparency was measured with a Secchi disc. The average values were total phosphorus $(26.5 \mu \mathrm{g} / \mathrm{L})$, total nitrogen (712 $\mu \mathrm{g} / \mathrm{L})$, chlorophyll a (5.2 $\mu \mathrm{g} / \mathrm{L}), \mathrm{pH}(8.07)$ and transparency (3.2 m).

\subsection{Fish health}

Fish health was monitored 30, 90 and 180 days after the beginning of the trial by inspection of skin and gills for external parasites or pathogen presence in kidney. During the monitoring, in the mornings, before removal of moribund and dead fish, two Nile tilapias were collected from each cage, totalling 42 (6 per treatment). Preference was given to moribund fish. These fish were packed individually in plastic bags, stored in an insulated box with ice and transported to the Aquatic Animal Disease Laboratory, which is located $120 \mathrm{~km}$ from the fish farm.

Upon arrival to the laboratory, the fish were individually weighed, and smears were prepared from each skin and gills for microscopic examination to investigate the occurrence of parasites. After this procedure, fish body surfaces were disinfected with alcohol $\left(70^{\circ} \mathrm{GL}\right)$ for $10 \mathrm{~min}$, and microbiological samples consisting of swabs were taken aseptically from the kidneys of the fish inside laminar flow. The samples were identified by means of routine tests, including colony morphology, Gram staining, haemolysis on agar containing sheep blood $5 \% \mathrm{v} / \mathrm{v}$, oxidase and phenotypic profiles in API $20 \mathrm{E}$ and API 20 Strep (BioMerieux, France). The prevalence of pathogens (number of infected or infested fish/total number of fish evaluated) and mean intensity (total number of monogenean external parasites/total number of fish examined) were calculated as described by Bush et al. (1997).

\subsection{Statistical analyses}

The assumptions of ANOVA were assessed using the Shapiro-Wilk test for normality on residuals and Levene's test for homogeneity of variance. Data on growth performance were subjected to two-way ANOVA to test the influence of the main effects (three stocking density and two feeding regimes) and the interaction between them in cages with bamboo substrates. The control group (CTRL) was compared to the treatment with substrate in the same density and feeding regimen by Test-t. In two-way ANOVA there was no interaction in all evaluated parameters. Thus, to compare the main effects together and to evaluate the difference among the CTRL (usually adopted by Brazilian farmers) and all treatments with bamboo substrate, data were subject to oneway ANOVA (Zar, 2010), followed by Tukey's test $(p<0.05)$.

\section{Results}

In the first 60 days after the beginning of the experiment, all treatments showed similar growth performance. At 90 days, all treatments that received $100 \%$ of daily ration had a higher average weight than those fed $50 \%$ of daily ration. From 120 to 180 days, the presence of bamboo substrates improved the average weight of fish fed two meals a day compared to the CTRL. However, at 180 days, fish stocked at $80 \mathrm{~kg} / \mathrm{m}^{3}$ in cages with substrates appeared to reach their carrying capacity because their mean weight stabilized during the next 20 days, while the CTRL group continued to grow (Fig. 2).

Growth performance was evaluated at three growth phases in order to assess the capacity of Nile tilapia to consume natural food in each phase. Fish fed $100 \%$ of daily ration in cages with substrates had the highest daily weight gain, followed by the CTRL group. The fish fed $50 \%$ of the diet in cages with substrates had the lowest daily weight gain among all (Table 2).

Conversely, during all evaluations of growth performance, there was a direct relationship between stocking density and feed conversion ratio (FCR) and between feeding ratio and FCR. For the third period (fish $800 \mathrm{~g}$ ), the higher the stocking density, the higher the FCR and fish fed $100 \%$ of daily ration had higher FCRs than fish fed $50 \%$ of the diet. For fish with $500 \mathrm{~g}$, the substrate in the cages reduced the FCR compared to fish stocked at the same density in cages of the CTRL group. At the end of the experiment all treatments showed the same uniformity (coefficient of variation) (Table 2).

The prevalence and mean intensity of pathogens were higher at the beginning of the trial, when the fish weighed $<75 \mathrm{~g}$. In this phase, the highest prevalence and mean intensity of monogenean Dactylogyridae in Nile tilapia gills was observed in the CTRL group. At the end of the trial, the CTRL group showed the lowest prevalence and mean intensity of this parasite, and fish stocked at the highest density with substrates for periphyton and fed two meals a day showed the highest prevalence and mean intensity of monogenean (Table 3).

The experiment began during the winter, when the water temperature was $20.8^{\circ} \mathrm{C}$ and the dissolved oxygen content was $7.5 \mathrm{mg} / \mathrm{L}$. The experiment ended during the summer with a temperature of approximately $30{ }^{\circ} \mathrm{C}$ and dissolved oxygen under $3 \mathrm{mg} / \mathrm{L}$. In the period between 50 and 140 days of the trial, dissolved oxygen inside the cages of the CTRL group was lower than that in cages with substrates.

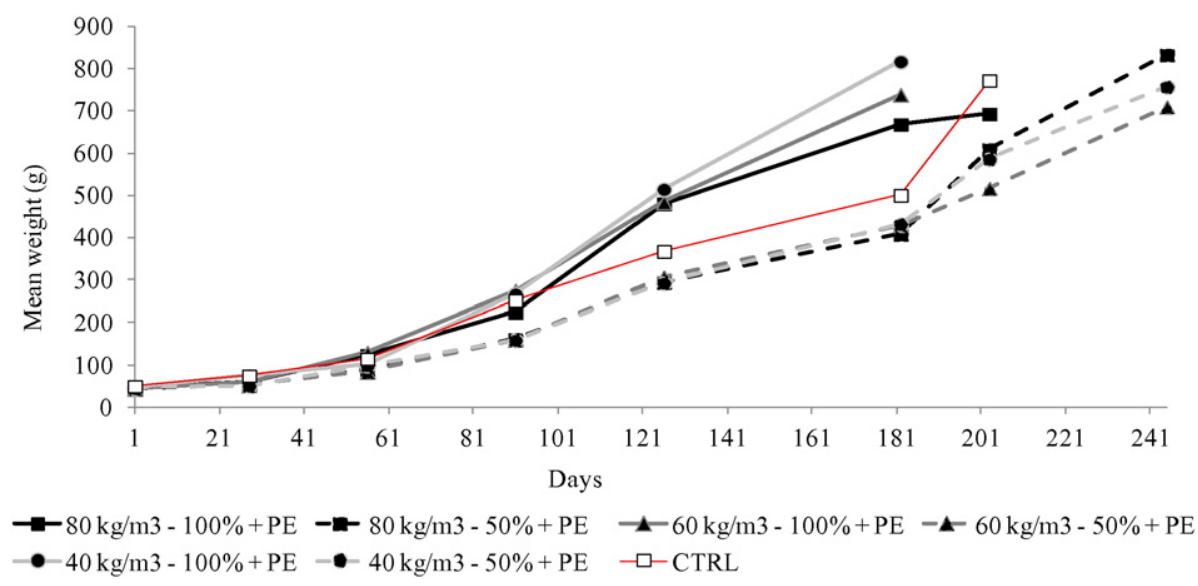

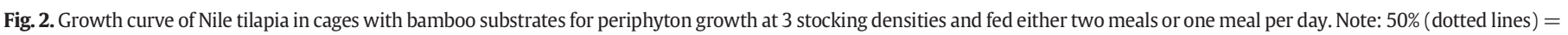
one meal per day; $100 \%$ (solid lines) = two meals per day; $+\mathrm{PE}=$ with substrate to periphyton. 
Table 2

Growth performance of Nile tilapia in cages with bamboo substrates for periphyton growth at 3 stocking densities and fed either two meals or one meal per day.

\begin{tabular}{|c|c|c|c|c|c|c|c|c|}
\hline \multicolumn{2}{|c|}{ (n) } & $50 \%+\mathrm{PE}$ & $100 \%+P E$ & $50 \%+\mathrm{PE}$ & $100 \%+P E$ & $50 \%+P E$ & $100 \%+P E$ & $100 \%$ \\
\hline Initial s & tocking density & \multicolumn{2}{|c|}{$15 \mathrm{~kg} / \mathrm{m} 3$} & \multicolumn{2}{|c|}{$22 \mathrm{~kg} / \mathrm{m} 3$} & \multicolumn{3}{|c|}{$30 \mathrm{~kg} / \mathrm{m} 3$} \\
\hline \multicolumn{2}{|c|}{ Initial weight $(\mathrm{g})^{2}$} & $45.67 \pm 0.78$ & $47.10 \pm 3.38$ & $45.67 \pm 3.93$ & $44.60 \pm 1.50$ & $43.75 \pm 1.75$ & $48.40 \pm 1.88$ & $50.77 \pm 4.56$ \\
\hline & Number of fish (fish/m3) ${ }^{2}$ & 55 & 55 & 82 & 82 & 110 & 110 & 110 \\
\hline Phase & Fish weight $(\mathrm{g})^{2}$ & 300.00 & 300.00 & 300.00 & 300.00 & 300.00 & 300.00 & 300.00 \\
\hline \multirow[t]{8}{*}{1} & Weight gain $(\mathrm{g} / \mathrm{fish})^{2}$ & $254.33 \pm 1.35$ & $252.90 \pm 5.85$ & $254.33 \pm 6.81$ & $255.40 \pm 2.60$ & $256.25 \pm 2.47$ & $251.60 \pm 3.25$ & $249.23 \pm 7.84$ \\
\hline & Survival $(\%)^{2}$ & $92.32 \pm 2.11$ & $90.61 \pm 3.74$ & $93.74 \pm 1.04$ & $91.38 \pm 1.33$ & $95.53 \pm 0.68$ & $94.04 \pm 0.94$ & $94.18 \pm 1.73$ \\
\hline & 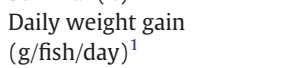 & $2.03 \pm 0.01 \mathrm{~d}$ & $2.66 \pm 0.04 \mathrm{a}$ & $2.03 \pm 0.03 \mathrm{~d}$ & $2.69 \pm 0.02 \mathrm{a}$ & $1.97 \pm 0.01 \mathrm{~d}$ & $2.52 \pm 0.02 b$ & $2.37 \pm 0.04 c$ \\
\hline & Specific growth rate $(\% / \text { day })^{1}$ & $1.51 \pm 0.01 \mathrm{c}$ & $1.95 \pm 0.08 \mathrm{ab}$ & $1.51 \pm 0.07 \mathrm{c}$ & $2.01 \pm 0.04 \mathrm{a}$ & $1.48 \pm 0.03 c$ & $1.83 \pm 0.04 \mathrm{ab}$ & $1.70 \pm 0.08 \mathrm{bc}$ \\
\hline & Feed consumed $(\mathrm{g} / \mathrm{fish})^{1}$ & $235.98 \pm 5.13 a$ & $244.03 \pm 21.36 \mathrm{ab}$ & $227.93 \pm 18.07 \mathrm{a}$ & $294.86 \pm 13.50 a b c$ & $252.27 \pm 7.69 \mathrm{ab}$ & $309.39 \pm 17.65 b c$ & $336.64 \pm 6.63 c$ \\
\hline & Feed conversion ratio ${ }^{1}$ & $0.93 \pm 0.02 \mathrm{a}$ & $0.97 \pm 0.08 \mathrm{ab}$ & $0.90 \pm 0.08 \mathrm{a}$ & $1.16 \pm 0.06 \mathrm{abc}$ & $0.98 \pm 0.04 \mathrm{ab}$ & $1.23 \pm 0.08 b c$ & $1.35 \pm 0.02 c$ \\
\hline & Productive cycle (days) ${ }^{2}$ & 125 & 92 & 125 & 95 & 130 & 100 & 105 \\
\hline & Stocking density & \multicolumn{2}{|c|}{$25 \mathrm{~kg} / \mathrm{m} 3$} & \multicolumn{2}{|c|}{$37 \mathrm{~kg} / \mathrm{m} 3$} & \multicolumn{3}{|c|}{$50 \mathrm{~kg} / \mathrm{m} 3$} \\
\hline Phase & Fish weight $(\mathrm{g})^{2}$ & 500.00 & 500.00 & 500.00 & 500.00 & 500.00 & 500.00 & 500.00 \\
\hline \multirow[t]{8}{*}{2} & Weight gain $(\mathrm{g} / \mathrm{fish})^{2}$ & $454.33 \pm 1.35$ & $452.90 \pm 5.85$ & $454.33 \pm 6.81$ & $455.40 \pm 2.60$ & $456.25 \pm 2.47$ & $451.60 \pm 3.25$ & $449.23 \pm 7.84$ \\
\hline & Survivors $(\%)^{2}$ & $90.20 \pm 2.04$ & $90.51 \pm 3.71$ & $91.92 \pm 1.68$ & $91.31 \pm 1.26$ & $90.91 \pm 0.61$ & $93.94 \pm 0.84$ & $92.29 \pm 2.45$ \\
\hline & 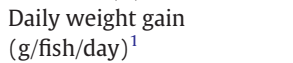 & $2.39 \pm 0.00 \mathrm{~d}$ & $3.74 \pm 0.03 \mathrm{a}$ & $2.39 \pm 0.02 \mathrm{~d}$ & $3.64 \pm 0.01 b$ & $2.40 \pm 0.01 \mathrm{~cd}$ & $3.61 \pm 0.02 b$ & $2.50 \pm 0.03 c$ \\
\hline & Specific growth rate $(\% / \text { day })^{1}$ & $1.26 \pm 0.01 \mathrm{~b}$ & $1.96 \pm 0.06 \mathrm{a}$ & $1.26 \pm 0.04 \mathrm{~b}$ & $1.93 \pm 0.03 \mathrm{a}$ & $1.28 \pm 0.02 \mathrm{~b}$ & $1.87 \pm 0.03 \mathrm{a}$ & $1.27 \pm 0.05 \mathrm{~b}$ \\
\hline & Feed consumed $(\mathrm{g} / \mathrm{fish})^{1}$ & $495.55 \pm 10.87 b$ & $475.61 \pm 76.13 b$ & $484.33 \pm 28.85 b$ & $554.39 \pm 13.73 a b$ & $580.07 \pm 11.42 \mathrm{ab}$ & $486.12 \pm 27.77 b$ & $717.71 \pm 21.29 a$ \\
\hline & Feed conversion ratio ${ }^{1}$ & $1.09 \pm 0.03 \mathrm{a}$ & $1.05 \pm 0.17 \mathrm{a}$ & $1.07 \pm 0.07 \mathrm{a}$ & $1.22 \pm 0.03 \mathrm{ab}$ & $1.27 \pm 0.00 \mathrm{ab}$ & $1.08 \pm 0.06 \mathrm{a}$ & $1.60 \pm 0.04 b$ \\
\hline & Productive cycle (days) ${ }^{2}$ & 190 & 121 & 190 & 125 & 190 & 125 & 180 \\
\hline & Stocking density & \multicolumn{2}{|c|}{$40 \mathrm{~kg} / \mathrm{m} 3$} & \multicolumn{2}{|c|}{$60 \mathrm{~kg} / \mathrm{m} 3$} & \multicolumn{3}{|c|}{$80 \mathrm{~kg} / \mathrm{m} 3$} \\
\hline Phase & Final weight $(\mathrm{g})^{2}$ & $818.85 \pm 26.98$ & $758.52 \pm 18.66$ & $740.37 \pm 23.15$ & $711.11 \pm 60.69$ & $694.80 \pm 53.81$ & $834.80 \pm 25.13$ & $773.71 \pm 32.35$ \\
\hline \multirow[t]{8}{*}{3} & Weight gain $(\mathrm{g} / \mathrm{fish})^{2}$ & $711.42 \pm 17.69$ & $773.19 \pm 22.15$ & $694.70 \pm 17.08$ & $666.51 \pm 58.81$ & $651.07 \pm 33.12$ & $786.40 \pm 53.08$ & $722.95 \pm 38.47$ \\
\hline & Survivors $(\%)^{2}$ & $79.39 \pm 3.54$ & $77.27 \pm 3.67$ & $79.73 \pm 2.58$ & $85.52 \pm 1.79$ & $77.05 \pm 3.86$ & $67.58 \pm 13.03$ & $75.79 \pm 3.27$ \\
\hline & $\begin{array}{l}\text { Daily weight gain } \\
\text { (g/fish/day })^{1}\end{array}$ & $3.07 \pm 0.04 b c$ & $3.91 \pm 0.07 \mathrm{a}$ & $2.68 \pm 0.04 \mathrm{c}$ & $3.53 \pm 0.18 a b$ & $2.66 \pm 0.01 \mathrm{c}$ & $3.62 \pm 0.14 \mathrm{a}$ & $3.56 \pm 0.11 \mathrm{ab}$ \\
\hline & Specific growth rate $(\% / \text { day })^{1}$ & $1.15 \pm 0.00 \mathrm{~d}$ & $1.53 \pm 0.03 \mathrm{a}$ & $1.08 \pm 0.03 \mathrm{~d}$ & $1.46 \pm 0.02 \mathrm{ab}$ & $1.13 \pm 0.02 \mathrm{~d}$ & $1.31 \pm 0.02 c$ & $1.35 \pm 0.05 \mathrm{bc}$ \\
\hline & Feed consumed $(\mathrm{g} / \mathrm{fish})^{1}$ & $815.26 \pm 71.27 a$ & $1133.39 \pm 90.40 a b$ & $849.00 \pm 16.26 a$ & $1069.36 \pm 57.66 \mathrm{ab}$ & $839.96 \pm 9.97 \mathrm{a}$ & $1414.03 \pm 103.48 b$ & $1331.79 \pm 78.42 b$ \\
\hline & Feed conversion ratio ${ }^{1}$ & $1.06 \pm 0.10 \mathrm{a}$ & $1.59 \pm 0.11 b c$ & $1.22 \pm 0.02 \mathrm{a}$ & $1.61 \pm 0.05 \mathrm{bc}$ & $1.29 \pm 0.01 \mathrm{ab}$ & $1.79 \pm 0.06 c$ & $1.84 \pm 0.05 c$ \\
\hline & Productive cycle (days) ${ }^{2}$ & 252 & 182 & 259 & 189 & 245 & 217 & 203 \\
\hline & Coefficient of variation $(\%)^{2}$ & $30.31 \pm 1.70$ & $25.35 \pm 1.94$ & $25.27 \pm 1.31$ & $22.41 \pm 3.32$ & $25.75 \pm 2.02$ & $21.87 \pm 1.28$ & $24.69 \pm 1.54$ \\
\hline
\end{tabular}

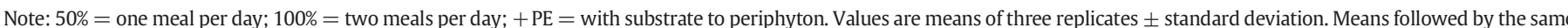
letter in the line: no significant difference (Tukey $p>0.05$ ).

1 Parameter subjected to ANOVA

2 Parameter did not subjected to ANOVA.

Table 3

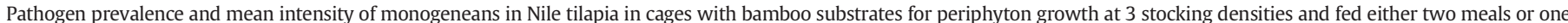
meal per day.

\begin{tabular}{|c|c|c|c|c|c|c|c|c|c|}
\hline \multirow[b]{2}{*}{ Time } & \multirow[b]{2}{*}{$\begin{array}{l}\text { Stocking density } \\
\left(\mathrm{kg} / \mathrm{m}^{3}\right)\end{array}$} & \multirow[b]{2}{*}{ Feed } & \multirow[b]{2}{*}{$\begin{array}{l}\text { Fish Weight } \\
(\mathrm{g})\end{array}$} & \multicolumn{5}{|c|}{ Prevalence (\%) } & \multirow{2}{*}{$\begin{array}{l}\text { Mean intensity (parasites/fish) } \\
\text { Dactylogyridae } \\
\text { (Gill) }\end{array}$} \\
\hline & & & & $\begin{array}{l}\text { Trichodina } \\
\text { (Skin) }\end{array}$ & $\begin{array}{l}\text { Gyrodactylidae } \\
\text { (Skin) }\end{array}$ & $\begin{array}{l}\text { Trichodina } \\
\text { (Gill) }\end{array}$ & $\begin{array}{l}\text { Dactylogyridae } \\
\text { (Gill) }\end{array}$ & $\begin{array}{l}\text { Aeromonas sp. } \\
\text { (Kidney) }\end{array}$ & \\
\hline \multirow[t]{7}{*}{30 days } & 80 & $100 \%$ & 61.25 & 33.3 & 16.7 & 0 & 100 & 0 & 304 \\
\hline & & $100 \%+P E$ & 42.55 & 0 & 0 & 0 & 100 & 16.7 & 168 \\
\hline & & $50 \%+P E$ & 51.02 & 16.7 & 0 & 0 & 100 & 0 & 232 \\
\hline & 60 & $100 \%+P E$ & 48.00 & 16.7 & 0 & 16.7 & 66.7 & 16.7 & 216 \\
\hline & & $50 \%+\mathrm{PE}$ & 52.49 & 16.7 & 16.7 & 16.7 & 50 & 0 & 224 \\
\hline & 40 & $100 \%+P E$ & 74.28 & 33.3 & 0 & 0 & 66.7 & 0 & 160 \\
\hline & & $50 \%+P E$ & 49.20 & 16.7 & 16.7 & 16.7 & 33.3 & 0 & 80 \\
\hline \multirow[t]{7}{*}{90 days } & 80 & $100 \%$ & 275.39 & 0 & 0 & 0 & 50 & 0 & 64 \\
\hline & & $100 \%+P E$ & 209.25 & 0 & 0 & 0 & 16.7 & 0 & 16 \\
\hline & & $50 \%+P E$ & 126.90 & 0 & 0 & 0 & 66.7 & 0 & 80 \\
\hline & 60 & $100 \%+P E$ & 273.69 & 0 & 0 & 0 & 66.7 & 0 & 56 \\
\hline & & $50 \%+\mathrm{PE}$ & 173.04 & 0 & 0 & 0 & 66.7 & 0 & 32 \\
\hline & 40 & $100 \%+P E$ & 207.15 & 0 & 0 & 0 & 66.7 & 0 & 24 \\
\hline & & $50 \%+P E$ & 190.05 & 0 & 0 & 16.7 & 50 & 0 & 64 \\
\hline \multirow[t]{7}{*}{180 days } & 80 & $100 \%$ & 547.62 & 16.7 & 0 & 0 & 16.7 & 0 & 8 \\
\hline & & $100 \%+\mathrm{PE}$ & 526.12 & 33.3 & 16.7 & 16.7 & 50 & 0 & 120 \\
\hline & & $50 \%+P E$ & 230.00 & 0 & 0 & 0 & 50 & 0 & 24 \\
\hline & 60 & $100 \%+P E$ & 420.80 & 16.7 & 0 & 33.3 & 33.3 & 0 & 40 \\
\hline & & $50 \%+\mathrm{PE}$ & 397.32 & 0 & 0 & 0 & 33.3 & 0 & 32 \\
\hline & 40 & $100 \%+\mathrm{PE}$ & 535.80 & 0 & 0 & 0 & 50 & 0 & 48 \\
\hline & & $50 \%+\mathrm{PE}$ & 262.20 & 0 & 0 & 0 & 50 & 0 & 88 \\
\hline
\end{tabular}

Note: $50 \%=$ one meal per day; $100 \%=$ two meals per day; $+\mathrm{PE}=$ with substrate to periphyton. 


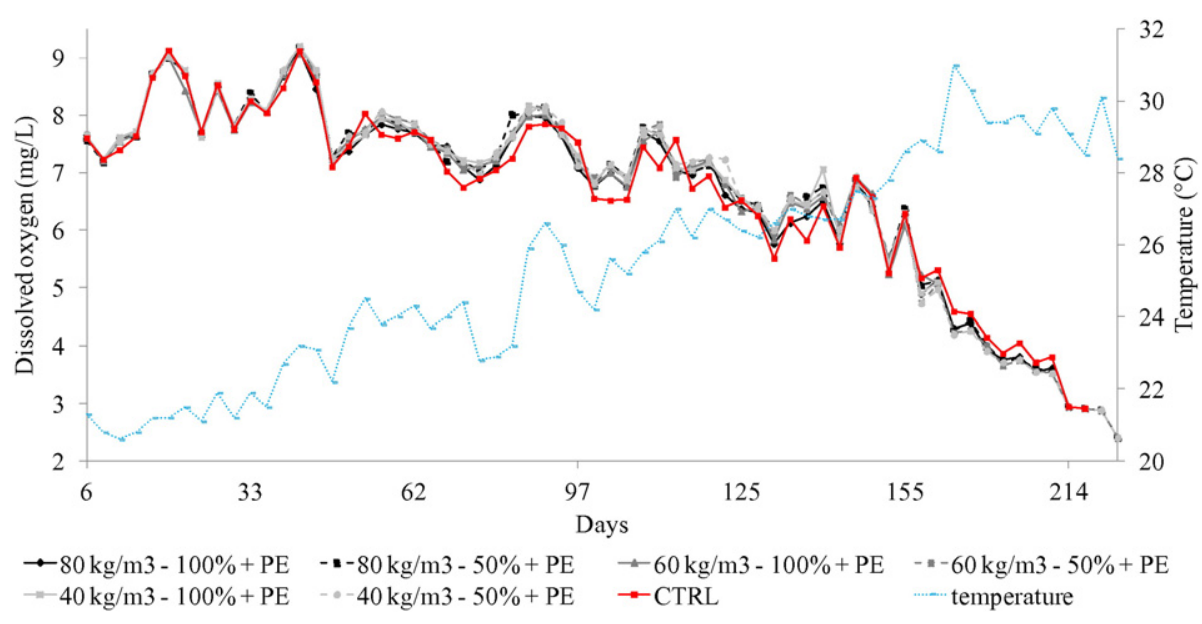

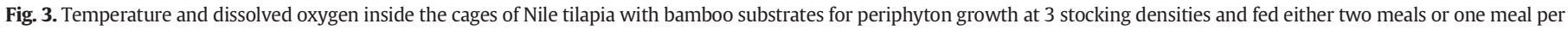
day. Note: $50 \%=$ one meal per day; $100 \%=$ two meals per day; $+\mathrm{PE}=$ with substrate to periphyton.

This period can be characterized as the autotrophic stage of the periphyton. After 155 days, cages with substrate showed a lower dissolved oxygen levels than cages of the CTRL, corresponding to the heterotrophic stage of the periphyton (Fig. 3).

\section{Discussion}

This study demonstrates the benefits of bamboo substrates in cages for Nile tilapia farming, at least until they reach $500 \mathrm{~g}$. While in ponds, studies have attested the potential of periphyton as a robust source of quality food for stocked fish (Keshavanath et al., 2004; Saikia and Das, 2009), in cages neither Norberg (1999) nor Huchette and Beveridge (2003) found periphyton-based cage culture to be viable. In floating cages in an earthen pond, Sakr et al. (2015) showed that the reduction in dietary protein levels in the presence of periphyton substrates improved the performance of Nile tilapia juveniles and increased the cost-effectiveness in relation to the traditional strategy of providing tilapia with higher levels of protein and no periphyton.

In this study, there was a direct relationship between stocking density and feed conversion ratio (FCR) in cages with bamboo substrates as was previously observed by Garcia et al. (2013) in cages of Nile tilapia without substrates. Increased stocking density reduces the efficiency of the system. In an experiment to determine the appropriate biomass of caged Nile tilapia supporting maximum production of small tilapia in open water in an integrated cage-cum-pond system, Yi and Lin (2001) observed that final mean weight of caged tilapia decreased from $478 \mathrm{~g}$ in the treatment with one cage to $261 \mathrm{~g}$ in the treatment with four cages. The worst growth parameters in high stocked biomass is explained by the increased energy expenditure due to higher activity levels, higher excitation levels, greater metabolic costs and decreased growth due to growth limitations in overcrowded conditions (Ellis et al., 2002). Moreover, the prevalence and mean intensity of monogenean Dactylogyridae in Nile tilapia gills increased in fish stocked at higher densities with substrates (Table 3). Garcia et al. (2013) also reported that Nile tilapia at higher stocking densities (100 and $120 \mathrm{~kg} / \mathrm{m} 3$ ) in cages without substrates showed a higher prevalence of Trichodina sp. in the skin and Streptococcus agalactiae in kidney, and Yi and Lin (2001) showed that survival of caged tilapia decreased with increasing biomass of caged tilapia per pond.

The growth curve of Nile tilapia revealed the carrying capacity of fish in cages with substrates. At 180 days, fish stocked at the highest density $(80 \mathrm{~kg} / \mathrm{m} 3)$ in cages with substrates stabilized their weight during the next 20 days, while the CTRL group continued to grow. At that moment the biomass of fish stocked was approximately $52 \mathrm{~kg} / \mathrm{m}^{3}$. The five modules of bamboo substrates used in this experiment reduced the useful volume inside cages. In addition, at the end of the productive cycle heterotrophic processes dominated, resulting in a periphyton mat that was consumer of dissolved oxygen. The rigid surfaces of substrates in an oxygenated water column allow the development of autotrophic and heterotrophic populations. The development of periphyton involves positive and negative interactions between phytoplankton, autotrophic periphyton, heterotrophic microbial bottom communities, heterotrophic periphyton and all of the cultured species (Milstein et al., 2003). Community composition varies and is determined by diverse factors such as the nature of the substrate, the trophic state of the environment (Fernandes and Esteves, 2003) and the intensity of grazing on the periphyton (Azim et al., 2005). Several heterotrophic characteristics of the periphytic community must be directly related to the higher density of pioneering organisms (bacteria/fungi) in the colonization process (Moschini-Carlos and Henry, 1997), the reduction in periphytic organisms during the final stages and the storage of substrate of inorganic materials (Fernandes, 1997). In this case, the reduction on the density of periphytic organisms can be related to their natural maturation (at the final stage of their cycle) and because of the high intensity of grazing by large Nile tilapias.

In the last period, fish fed $50 \%$ of the recommended diet had better FCRs than fish fed $100 \%$ of the diet. Considering that the diet represents $>70 \%$ of the total production cost of Nile tilapia in cages (Ayroza et al., 2014), this improvement in the efficiency of the production system reducing $50 \%$ of diet can be advantageous. However, the time spent by the fish to reach the expected weight was longer in the groups fed $50 \%$ of the diet.

In the present trial, evaluation of growth performance in different sizes of fish $(300,500$ and $800 \mathrm{~g})$ showed that periphyton improved the weight gain of Nile tilapia at all sizes except at the end of the trial, which is likely due to the physical limitation of the available volume of the cage in this phase. In this phase stocking cages with substrates for periphyton with the higher tilapia biomass and supplying reduced feed amounts ( $80 \mathrm{~kg} / \mathrm{m} 3$ and one daily meal with substrate) it is possible to produce tilapia with $30 \%$ less diet than in the control, but with an increase of $20 \%$ in the culture period required to achieve the same target production. Several studies on the feeding ecology of adult tilapia of the genus Oreochromis have shown that algae and algae-derived detritus (phytoplankton, sedimented algae, benthic algae, periphytic algae) comprise the bulk of their gut contents. With assimilation efficiencies of $50-80 \%$, tilapiine cichlids appear to be adept at digesting plantbased food materials (Beveridge and Baird, 2000).

During the autotrophic phase of periphyton, in the present trial, the presence of bamboo substrate in the cages improved the weight gain of Nile tilapia. For fish that weighed $500 \mathrm{~g}$ at the higher stocking density 
( $50 \mathrm{~kg} / \mathrm{m} 3$ ), the substrate in the cages reduced by $32 \%$ the FCR and the feed consumed compared to fish stocked at the same density in cages of the CTRL. These results are in agreement with those of Sakr et al. (2015), who suggest that periphyton is a prime source of food for Nile tilapia in cages. The nutrient quality and availability of periphyton varies with grazing pasture, algal and bacterial taxonomic composition, nutrient concentration in the environment and, most significantly, with substrate type (Azim et al., 2002a). Azim et al. (2002a,b,c) found 15-29\% ash, $23-32 \%$ protein, $2-5 \%$ lipids and $33 \%$ carbohydrate in periphyton from bamboo substrates in their experimental earthen ponds. Moreover, the sestonic algal community is rich in $\omega-3$ PUFAs (Saikia and Nandi, 2010), and because attached life forms on aquatic substrates (as periphyton) have similar genetic origins, they also can be a source of $\omega-3$ PUFAs for higher trophic levels. Tilapiine cichlids have all four mechanisms of teleosts for breaking down plant material: pharyngeal jaws to grind the food, a muscular stomach to triturate ingested material, a highly acidic stomach that can lyse plant cells and/or a microbial fauna in the final gut. These features may explain their high assimilation efficiencies (Beveridge and Baird, 2000).

Little work has been conducted on the relationship between the periphyton community and the health of animals in aquatic systems. After reviewing all experiments conducted in Bangladesh and India, Azim and Asaeda (2005) suggest that fish survival is higher in periphyton-based pond production systems than in substrate-free production systems. In the present study, the prevalence and mean intensity of pathogens were higher at the beginning of the trial, when water temperature were lower $\left(21^{\circ} \mathrm{C}\right.$ to $\left.26^{\circ} \mathrm{C}\right)$ than the recommended for Nile tilapia. At the end of the trial, the CTRL group showed the lowest prevalence and mean intensity of monogenean Dactylogyridae. This parasite has a direct life cycle and is more frequently found in lentic environments. In addition, intensive fish farming favours the transmission of this parasite (Flores-Crespo and Flores-Crespo, 2003; Azevedo et al., 2007). In fact, at the end of the trial, heterotrophic processes dominated and oxygen levels were lower in cages with substrates. However, aside from the increased occurrence of Dactylogyridae in fish from cages with substrates, there was no significant difference $(p>0.05)$ in Nile tilapia survival between cages with or without substrate (CTRL), indicating that fish health was apparently similar between treatments. Azim et al. (2005) suggested that periphyton can improve fish health by offering them food, vitamins, probiotics, antimicrobial or antibiotic substances produced by microorganisms in the mat, and better shelter against predation in substrate-rich environments.

In conclusion, this study demonstrated the potential of periphytonbased cage culture of Nile tilapia in a Brazilian hydroelectric reservoir. The presence of bamboo substrates improved the weight gain of fish but reduced the carrying capacity of the cage for large tilapia sizes. Feed restriction ( $50 \%$ of recommended) reduced FCRs. The concentration of dissolved oxygen in the cages was improved by the presence of substrate between 50 and 140 days of the trial and reduced after 155 days of culture.

This study show that the inclusion of bamboo substrates in the cages allows producing up to $52 \mathrm{~kg} / \mathrm{m} 3$ of Nile tilapia using $32 \%$ less diet in a period almost $20 \%$ shorter than the CTRL group. If farmers prefer to produce $80 \mathrm{~kg} / \mathrm{m} 3$ they can use $30 \%$ less diet adding substrates for periphyton, however with an increase of $20 \%$ in the culture period required to achieved the same target production. At this density, new studies are encouraged to evaluate the growth performance of fish if the substrates were removed when the biomass reaches $52 \mathrm{~kg} / \mathrm{m}^{3}$ (carrying capacity).

This is the first study to demonstrate the efficiency of using substrates for Nile tilapia in cages in hydroelectric reservoirs, including adult fish, and complementary research on other aspects of this production system is encouraged. The reduction in FCR reduces the production cost and the farmer's dependence on external resources (commercial diet). Thus, this production model may be an efficient alternative for family farmers.

\section{Acknowledgments}

This study has been funded by the São Paulo Research Foundation (2013/18721-6) and grant 2014/08479-6. We thank Mr. Rodrigo Hirose and his employees (Piscicultura Sempre Viva) for the valuable contribution giving the location and operational support for the experiments. We thank Dr. Rogério Soares de Freitas (Instituto Agronômico de Campinas) for the technical support.

\section{References}

Ayroza, D.M.M.R., Garcia, F., Ayroza, L.M.S., Furlaneto, F.P.B., Ferraudo, A.S., Mercante C.T.J., 2014. Environmental conditions, fish disease, management and economic evaluation of tilapia cages in a Brazilian hydroelectric reservoir. In: Walkefield, R. (Ed.), Tilapia: Biology, Management Practices and Human Consumption. Nova Science Publishers, New York, pp. 119-145.

Azevedo, R.K., Abdallah, V.D., Luque, J.L., 2007. Ecologia da comunidade de metazoários parasitos do Apaiari Astronotus ocellatus (Cope, 1872) (Perciformes: Cichlidae) do rio Guandu, Estado de Rio de Janeiro, Brasil. Rev. Bras. Parasitol. Vet. 16, 15-20.

Azim, M.E., Asaeda, T., 2005. Periphyton structure, diversity and colonization. In: Azim, M.E., Verdegem, M.C.J., Van Dan, A.A., Beveridge, M.C.M. (Eds.), Periphyton: Ecology, Exploitation and Management. CABI Publishing, Cambridge, pp. 15-33.

Azim, M.E., Wahab, M.A., Verdegem, M.C.J., Van Dan, A.A., Van Rooij, M.J., Beveridge, M.C.M., 2002a. The effects of artificial substrates on freshwater pond productivity and water quality and the implications for periphyton-base aquaculture. Aquat. Living Resour. 15, 231-241.

Azim, M.E., Verdegem, M.C.J., Rahman, M.M., Wahab, M.A., Van Dan, J.M., Beveridge M.C.M., 2002b. Evaluation of polyculture of Indian major carps in periphyton-based ponds. Aquaculture 213, 131-149.

Azim, M.E., Verdegem, M.C.J., Khatoon, H., Wahab, M.A., Van Dam, A.A., Beveridge, M.C.M., 2002c. A comparison of fertilization, feeding and three periphyton substrates for increasing fish production in freshwater pond aquaculture in Bangladesh. Aquaculture 212, 231-247.

Azim, M.E., Verdegem, M.C.J., Van Dam, A.A., Beveridge, M.C.M., 2005. Periphyton: Ecology, Exploitation and Management. CABI Publishing, Cambridge, UK (319 pp).

Beveridge, M.C.M., Baird, D.J., 2000. Diet, feeding and digestive physiology. In: Beveridge, M.C.M., McAndrew, B.J. (Eds.), Tilapias: Biology and Exploitation. Kluwer Academic Publishers, Dordrecht, NED, pp. 59-87.

Bush, A.O., Lafferty, K.D., Lotz, J.M., Shostak, A.W., 1997. Parasitology meets ecology on its own terms. J. Parasitol. 83 (4), 575-583.

Dempster, P.W., Beveridge, M.C.M., Baird, D.J., 1993. Herbivory in the tilapia Oreochromis niloticus (L.): a comparison of feeding rates on periphyton and phytoplankton. J. Fish Biol. 43, 385-392.

Ellis, T., North, B., Scaott, A.P., Bromage, N.R., Porter, M., Gadd, D., 2002. The relationships between stocking density and welfare in farmed rainbow trout. J. Fish Biol. 61, 493-531.

Fernandes, V.O., 1997. Variação Temporal Da Estrutura e dinâmica Da Comunidade perifítica, Em Dois Tipos de Substrato, na Lagoa Imboassica, Macaé (RJ). PhD dissertation. Universidade Federal de São Carlos, São Carlos, SP, BRA.

Fernandes, V.O., Esteves, F.A., 2003. The use of indices for evaluating the periphytic community in two kinds of substrate in Imboassica Lagoon, Rio de Janeiro, Brazil. Braz. J. Biol. 63-2, 233-243.

Flores-Crespo, R., Flores-Crespo, J., 2003. Monogeneos, parásitos de peces en México. Estudio recapitulaivo. Téc Pec Méx. 41, pp. 175-192.

Garcia, F., Romera, D.M., Gozi, K.S., Onaka, E.M., Fonseca, F.S., Schalch, S.H.C., Candeira, P.G., Guerra, L.O., Carmo, F.J., Carneiro, D.J., Martins, M.I.E., Portella, M.C., 2013. Stocking density of Nile tilapia in cages placed in a hydroelectric reservoir. Aquaculture 410 411 (51-56).

GLOBEFISH Highlights, 2013. FAO/GLOBEFISH Highlights (3/2013): p. 61.

Huchette, S.M.H., Beveridge, M.C.M., 2003. Technical and economical evaluation of periphyton-based cage culture of tilapia (Oreochromis niloticus) in tropical freshwater cages. Aquaculture 218, 219-234.

Keshavanath, P., Gangadhar, B., Ramesh, T.J., Van Dam, A.A., Beveridge, M.C.M., Verdegem, M.C.J., 2004. Effects of bamboo substrate and supplemental feeding on growth and production of hybrid red tilapia fingerlings (Oreochromis mossambicus x Oreochromis niloticus). Aquaculture 235, 303-314.

Marker, A.F.H., Nusch, E.A., Rai, H., Riemann, B., 1980. The measurement of photosynthetic pigments in freshwaters and standardization of methods: conclusions and recommendations. Arch. Hydrob. Bull. 14, 91-106.

Milstein, A., Azim, M.E., Wahab, A.W., Verdegem, M.C.J., 2003. The effect of periphyton, fish and fertilizer dose on biological process affecting water quality in earthen fish ponds. Environ. Biol. Fish 68, 247-260.

Moschini-Carlos, V., Henry, R., 1997. Aplicação de índices para a classificação do perifíton em substratos natural e artificial, na zona de desembocadura do rio Paranapanema (Represa de Jurumirim), SP. Rev. Bras. Biol. 57-4, 655-663.

Norberg, J., 1999. Periphyton fouling as a marginal energy source in tropical tilapia cage farming. Aquac. Res. 30, 427-430.

Rojas, A., Wadsworth, S., 2007. A review of cage culture: Latin America and the Caribbean. In: Cage aquaculture - regional reviews and global overview. In: Halwart, M., Soto, D. Arthur, J.R. (Eds.), Cage Aquaculture - Regional Reviews and Global Overview. FAO Technical Paper, Rome, pp. 70-100.

Saikia, S.K., Das, D.N., 2009. Potentiality of periphyton - based aquaculture technology in rice-fish environment. J. Sci. Res. 1 (3), 624-634. 
Saikia, S.K., Nandi, S., 2010. C and P in aquatic food chain: a review on C:P stoichiometry and PUFA regulation. Knowl. Manag. Aquat. Ecosyst. 398 (03), 1-14.

Sakr, E.M., Shalaby, S.M., Wassef, E.A., El-Sayed, A.M., Abdel-Moneim, A.I., 2015. Evaluation of periphyton as a food source for Nile tilapia (Oreochromis niloticus) juveniles fed reduced protein levels in cages. J. Appl. Aquac. 27, 50-60.

Valderrama, J.C., 1981. The simultaneous analysis of total nitrogen and total phosphorus in natural waters. Mar. Chem. 10 (2), 109-122.

Watanabe, W.O., Clarck, J.H., Dunham, J.B., Wicklund, R.I., Olla, B.L., 1992. Culture of Florida red tilapia in marine cages: the effect of stocking density and dietary protein on growth. 42th Proc 44th Annual Gulf and Caribbean Fisheries Institute, Charleston, SC, pp. 449-454.

Yi, Y., Lin, C.K., 2001. Effects of biomass of caged Nile tilapia (Oreochromis niloticus) and aeration on the growth and yields in an integrated cage-cum-pond system. Aquaculture 195 (3-4), 253-267.

Zar, J.H., 2010. Biostatistical Analysis. Prentice Hall, NJ. 